\title{
Sosialisasi Peraturan Perlombaan Panahan Di Lingkungan Priangan Tengah
}

\author{
${ }^{1}$ Andi Kurniawan Pratama, ${ }^{2}$ Muhamad Syamsul Taufik, ${ }^{3}$ Adi Rahadian. \\ ${ }^{1}$ Fakultas Keguruan Ilmu Pendidikan, Universitas Suryakancana, Jawa Barat, Indonesia \\ Email: andikpratama@unsur.ac.id ${ }^{1}$, syamsul@unsur.ac.id ${ }^{2}$, adira@unsur.ac.id ${ }^{3}$
}

Diterima: 28 Mei 2020; Revisi: 29 Mei 2020; Disetujui: 29 Mei 2020

\begin{abstract}
The problem in this activity is the lack of knowledge and understanding of the archers and also the trainers of the archery competition rules. Whereas in general, the rules of a competition will be distributed through the Technical Handbook of the championship. The targets of this socialization activity are archery lovers, be it athletes, club coaches, archery extracurricular trainers or hobbyists in the Central Priangan area covering the area of Bandung City, Bandung Regency, West Bandung Regency, Cimahi City and Sumedang Regency. there is an increase in the understanding of athletes and archery coaches both at club and extracurricular levels on archery competition rules by 17.8\%. The network of this archery competition was carried out through a socialization method which was divided into 3 stages (Orientation, Implementation and Evaluation).
\end{abstract}

Keywords: Socialization,Rrace Rules, Archery

Abstrak

Permasalahan dalam kegiatan ini adalah kurang pengetahuan dan pemahaman para pemanah dan juga pelatih terhadap peraturan perlombaan panahan. Padahal secara garis besar, peraturan perlombaan suatu pertandingan akan disebarkan melalui Technical Handbook kejuaraan. Sasaran dari kegiatan sosialisasi ini ialah para pecinta olahraga panahan baik itu atlet, pelatih klub, pelatih ekskul panahan ataupun para penghobi yang ada di lingkungan Priangan Tengah meliputi daerah Kota Bandung, Kabupaten Bandung, Kabupaten Bandung Barat, Kota Cimahi dan Kabupaten Sumedang. adanya peningkatan pemahaman atlet maupun pelatih panahan baik level klub ataupun ekskul terhadap peraturan perlombaan panahan sebesar $17,8 \%$. Jalanya kegiatan sosialisasi perlombaan panahan ini melalui metode sosilisasi yang terbagi ke dalam 3 tahap (Orientasi, Implementasi dan Evaluasi).

Kata Kunci: Sosialisasi, Peraturan Perlombaan, Panahan

\section{ANALISIS SITUASI}

Panahan merupakan salah satu olahraga yang sudah sejak lama ada di dunia. Akan tetapi sejarah mengatakan belum ada yang mengetahui dengan pasti kapan manusia mulai memanah. Namun pada tahun 1676 atas prakarsa Raja Charles II dari Inggris panahan mulai dipandang sebagai suatu cabang olahraga (Prasetyo, 2011) Menurut (Rahadian, 2018) Olahraga juga merupakan salah satu media untuk membuat kondisi kesehatan manusia menjadi lebih baik dan terjaga Olahraga panahan saat ini mempertandingkan empat divisi, yakni Divisi Recurve, Divisi Compound, Divisi Barebow dan Divisi Standar Bow dengan format bisa dilaksanakan outdoor maupun indoor. Menurut (MS. Taufik, 2019) Olaharaga yang memang tidak memandang umur.

Belakang ini olahraga panahan semakin dikenal oleh masyarakat luas, hal ini bisa dilihat dari semakin banyaknya kejuaraan-kejuaraan panahan yang diselenggarakan di Indonesia, khususunya yang ada dilingkungan Jawa Barat. Data dari Bidang Perlombaan Pengprov Perpani Jawa Barat (2020), menyebutkan bahwa sepanjang tahun 2018 sampai 2019 hampir tiap bulan ada kejuaraan yang diselenggarakan di lingkungn Jawa Barat. Bukan hanya itu, hal lain yang bisa terlihat ialah semakin 


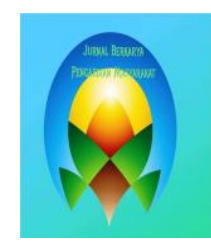

Journal Berkarya

Pengabdian kepada Masyarakat

Vol. 2, No. 1, Mei, 2020,

E-ISSN 2686-6218

banyak pula klub-klub panahan yang berdiri baik hanya sebagai klub untuk penghobi ataupun sebagai sarana untuk menyalurkan bakat yang berujung prestasi.

Menurut (Ilham \& Oktadinata, 2018) Pengertian olahraga dalam UU No.3 Tahun 2005 tentang Sistem Keolahragaan Nasional adalah segala kegiatan yang sistematis untuk mendorong dan membina, Dengan semakin berkembang dan populernya olahraga panahan, tidak menutup kemungkinan akan terjadi hal-hal yang tidak diinginkan seperti kurang terkontrolnya penjualan alat-alat panahan yang sesuai standar, tempat latihan yang kurang safety dan juga tidak berjalan dengan baik kejuaraankejuaraan yang dilaksanakan karena minimnya pengetahuan mengenai peraturan perlombaan.

Padahal ini semua sudah diterbitkan oleh organisasi olahraga panahan tertinggi di dunia yakni World Archery dan juga sudah diedarkan oleh PB Perpani selaku induk olahraga panahan Indonesia. Dari beberapa kali kejuaraan panahan open yang diselenggarakan di Indonesia khususnya di Jawa Barat, sering kali masih banyak atlet-atlet pemula yang mengikuti kejuaraan panahan kurang memahami peraturan perlombaan padahal peraturan pokok perlombaan panahan sudah tertuang dalam Technical Handbook kejuaraan yang biasanya sudah disebarkan oleh panitia kejuaraan.

Hal tersebut bisa dilihat dari belum pahamnya peraturan mengenai peralatan yang digunakan salah satunya seperti warna/corak busur yang diperbolehkan karena masih banyak yang menggunakan warna camo/kamuflase, tidak memakai sepatu, vanes yang belum seragam untuk semua anak panahnya, tidak memeriksakan peralatannya sebelum bertanding dan lain sebagainya. No denim or jeans, regardless the colour, or camouflage clothes and equipment may be worn nor any oversize or baggy type pants or shorts (World Archery, 2019) Sudah jelas bahwa pakaian berbahan denim atau jeans tidak diperbolehkan digunakan dalam pertandingan panahan, dan juga semua aksesoris panahan sekalipun.

Selain dari segi peralatan, para pemanah pemula juga masih banyak yang kebingungan mengenai aturan-aturan jalannya perlombaan seperti pemahaman mengenai jadwal perlombaan, waktu menembak, juga tata cara penghitungan skor pada scoring sheet dan juga masih banyak pemanah yang memegang anak panah sebelum proses pencatatan skor selesai. None of the arrows, the target face or butt shall be touched until the value of all the arrows on that butt has been recorded (World Archery, 2019). Akan tetapi hal ini seringkali terjadi dalam pertandingan panahan, si pemanah akan protes karena merasa tidak diuntungkan dengan hal tersebut padahal secara rulesnya sudah sangat jelas ada.

Apabila hal ini tidak segera ditanggulangi, maka tidak menutup kemungkinan pada setiap pertandingan panahan akan sering muncul masalah-masalah teknis terkait dengan jalannya pertandingan. Untuk menjawab hal tersebut yang dirasa mendesak maka harus dilakukan langkah sosialisasi peraturan perlombaan panahan sebagai salah satu cara supaya masyarakat pecinta panahan baik itu atlet maupun pelatih mempunyai wawasan yang baik serta mampu menerapkannya di lapangan pada saat pertandingan.

\section{SOLUSI DAN TARGET}

Solusi

Atlet, pelatih klub maupun pelatih ekskul yang memiliki pengetahuan yang baik mengenai peraturan perlombaan panahan dan mampu menerapkannya di lapangan pada saat pertandingan akan membantu berjalannya pertandingan panahan dengan lancar. Hal lainnya ialah akan memberikan keuntungan untuk atlet dan juga pelatih karena dengan mengetahui peraturan perlombaan.

\section{Target}

Setelah mengikuti sosialisasi peraturan perlombaan ini, diharapkan para atlet dan pelatih semakin memahami bagaimana aturan-aturan yang diperlohekan dan yang tidak diperbolehkan dalam perlombaan panahan. Untuk para pelatih diharapkan mampu mentrasfer pemahanan dan mempraktekannya pada saat latihan kepada atlet-atletnya sehingga tidak terjadi lagi ketidakpahaman yang terjadi pada saat pertandingan, khususnya yang ada di lingkungan Priangan Tengah.

\section{METODE PELAKSANAAN}

Dalam penyelenggaraan kegiatan sosialisasi peraturan perlombaan panahan ini, metode yang digunakan ialah metode sosialisasi yang terbagi menjadi 3 tahap.(Zarwan, Sefri Hardiansyah, 2019) 


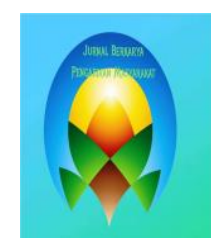

Journal Berkarya

Pengabdian kepada Masyarakat

Vol. 2, No. 1, Mei, 2020,

E-ISSN 2686-6218

Tahap pertama yakni orientasi, dimana dalam tahap ini tim melakukan pengkondisian peserta mulai dari menyebarkan surat undangan dan juga pamflet serat mendata peserta yang mengikuti kegiatan ini yang berasal dari klub-klub, ekskul panahan, penghobi dan para pecinta olahraga panahan lainnya yang berada di lingkungan Priangan Tengah yakni Kota Bandung, Kabupaten Bandung, Kabupaten Bandung Barat, Kota Cimahi \& Kabupaten Sumedang.

Yang kemudian didata dan dimasukan kedalam grup Whatsapp agar lebih memudahkan koordinasi. Kemudian tim mempersiapkan peralatan-peralatan yang akan digunakan pada saat sosialisasi seperti busur, anak panah, target face berbagai ukuran, bow scale, archery inspection ring, kaca pembesar, caliper, dll. Tak lupa juga tim menyiapakan power point untuk materi-materinya. Kemudian tim juga menentukan siapa yang akan menjadi pematerinya.

Tahap kedua yakni implementasi, yakni pelaksanaanya dilaksanakan pada tanggal 29 Februari 2020 yang bertempat di The Cipaku Garden Hotel mulai pukul 07.30 WIB sampai dengan pukul 17.00 WIB. Dalam kegaiatan sosialisasi ini membahas mengenai peraturan umum perlombaan panahan yang terdiri empat materi yang disampaikan, (1) Safety \& Target Layout in Archery (2) Inspection Procedures (3) Peraturan Umum Perlombaan Panahan (Tata Cara Penembakan, Signal Timer, Target Face) (4) Scoring.

Tahap ketiga yakni evaluasi, sharing bersama antara tim dengan peserta sosialisasi. Melalui evaluasi ini dapat diukur capaian yang didapat dari kegiatan pengabdian yang diselenggarakan dengan melihat persentase dari pretest dan posttest dengan menjawab pertanyaan-pertanyaan seputar peraturan perlombaan panahan.

\section{PELAKSANAAN KEGIATAN}

Kegiatan ini terdiri dua sesi, sesi pertama (dari pagi sampai istirahat siang) membahas mengenai Safety \& Target Layout in Archery serta Inspection Procedures yang diperbolehkan dalam perlombaan panahan. Kemudian sesi kedua (dari siang sampai sore) membahas mengenai peraturan umum perlombaan panahan yang meliputi tata cara penembakan, signal timer, target face yang digunakan, standar ukuran lapangan perlombaan panahan, target but, serta tata cara proses skoring.

Kegiatan dimulai pada pukul 07.30 WIB diawali dengan registrasi ulang. Dari 35 orang yang mendaftar, hanya 30 orang yang melakukan registrasi ulang untuk mengikuti kegiatan sosialisasi perlombaan ini. Sebelum sesi pertama dimulai, peserta diberikan pretest terlebih dahulu dengan menjawab pertanyaan-pertanyaan terkait peraturan perlombaan panahan dengan format multiple choice.

Untuk sesi yang pertama ini dibawakan oleh Bapak Adi Rahadian Materi pertama yakni Safety \& Target Layout in Archery membahas mengenai aspek keselamatan dalam panahan paling pertama yang harus diperhatikan ketika akan memanah, seperti tempat latihan atau pertandingan yang aman ataupun peralatan yang digunakan. Lapangan panahan yang aman untuk dijadikan tempat latihan ataupun kejuaraan ialah lapangan yang dibelakang targetnya tidak ada kegiatan sama sekali orang berlalulalang. Selanjutnya aspek keamanan dalam hal peralatan, yang pertama ialah busur yang digunakan sesuai dengan standar seperti berat tarikan busur dengan kriteria apabila busur compound tidak lebih dari $60 \mathrm{lbs}$.

Busur yang digunakan, komposisi limbsnya tidak dalam keadaan retak/rusak. Tali yang terpasang masih bagus tidak ada potongan-potongan. Pivot point pemasangan arrowrest sesuai dengan peraturan tidak terlalu jauh dari grip hal ini menjaga supaya tangan yang memegang busur agar dalam situasi yang aman apabila pada saat menarik anak panah terjatuh. Aspek keamanan dalam panahan selanjutnya ialah anak panah hanya diperbolehkan dipasang pada busur apabila sudah berada digaris tembak. Cara menarik busur juga tidak boleh terlalu tinggi dan mengarah ke langit, dan jangan mengarahkan ke orang lain ketika menraik busur apalagi ada anak panah yang sudah terpasang. Selalu mendengar dan melihat aba-aba penembakan, berhenti apabila sudah mendengar bel $3 \mathrm{x}$ atau signal lamp berubah menjadi merah.

Pada saat mau mengambil anak panah di target tidak boleh berlari dan berhati-hati saat mencabut anak panah ditarget bantalan dengan cara bergantian. Dalam materi peratama ini dimulai pukul 08.30 WIB sampai pukul 10.00 WIB. Selama 1,5 jam penyampaian materi alhamdulillah peserta 


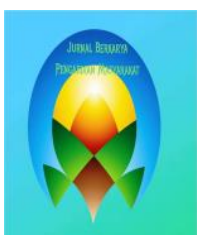

Journal Berkarya

Pengabdian kepada Masyarakat

Vol. 2, No. 1, Mei, 2020,

E-ISSN 2686-6218

terlihat sangat antusias. Kemudian pada pukul 10.30 WIB sampai pukul 11.00 WIB dilanjut dengan coffee break.

Selanjutnya pada pukul 11.00 WIB sampai pukul 12.00 WIB dilanjutkan dengan materi Inspection Procedures. Dalam materi ini pemateri memberikan praktek bagaimana tatacara melakukan pemeriksaan peralatan yang benar. Selain pemeriksaan peralatan, dalam materi ini juga membahas pakaian yang diperbolehkan, yakni tidak boleh memakai pakaian khususnya celana yang berbahan demim atau jeans dan juga tidak boleh memakai sandal di area perlombaan. Selain itu warna camo/kamuflase juga tidak diperbolehkan dalam olahraga panahan khususnya target archery. Aksesoris apa saja yang boleh dan tidak boleh digunakan. Untuk sesi ini para peserta diperbolehkan langsung bertanya apabila ada materi yang kurang jelas sehingga jalannya sosialisasi menjadi lebih atraktif.

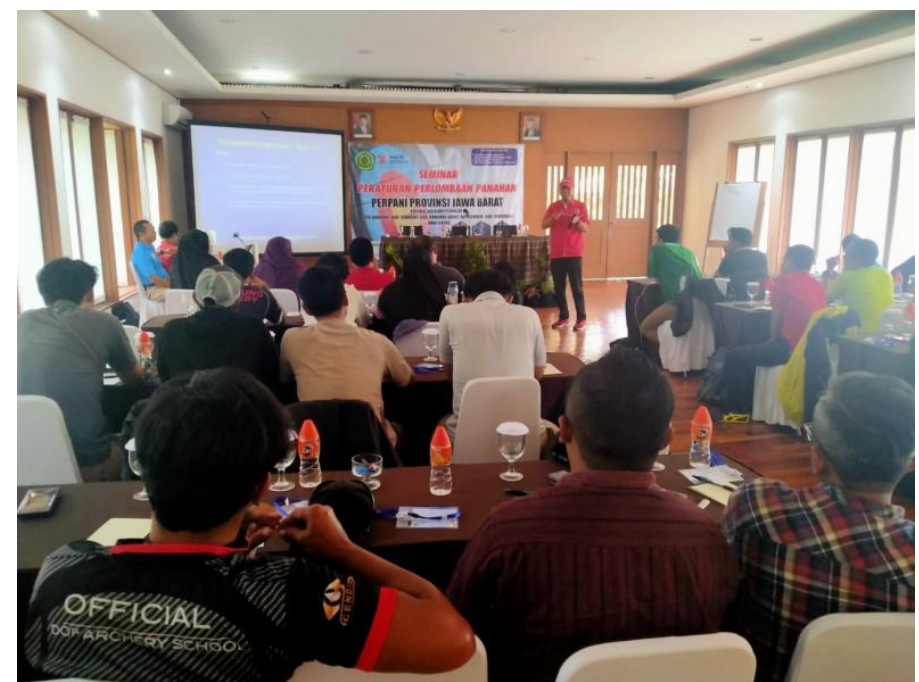

Gambar 1. Penjelasan Materi (Dok Pribadi)

Untuk sesi yang kedua dimulai pada pukul 13.00 WIB sampai pukul 14.30 WIB setelah kegiatan ishoma selesai. Materi yang pertama disampaikan ialah peraturan umum perlombaan panahan yang meliputi signal timer, target face yang digunakan, standar ukuran lapangan perlombaan panahan dan ukuran target butt. Dalam beberapa pertandingan, terkadang panitia penyelenggara tidak mengindahkan peraturan ukuran target butt, yang seharusnya minimal $124 \mathrm{~cm}$ x $124 \mathrm{~cm}$ terkadang hanya berukuran $100 \mathrm{~cm}$ x $100 \mathrm{~cm}$.

Pada target butt pun wajib dipasnag nomor target dengan ukuran tinggi $30 \mathrm{~cm}$ dengan ketentuan nomor hitam pada latar belakang/papan berwarna kuning dan bergantian. Begitu dengan ukuran lajur bantalan, yang seharusnya atlet mempunyai hak $80 \mathrm{~cm}$ pada saat penembakan terkadang hanya mendapatkan hak $60 \mathrm{~cm}$. Pada materi ini juga dijelaskan signal timer, bel 2x (lampu berwarna merah) para atlet masuk ke garis tembak dan mempunyai waktu pre game 10 detik, bel 1x (lampu berwarna hijau) diperbolehkan menembak dan bel 3x (lampu berwarna merah) para atlet berhenti memanah. Untuk lampu berwarna kuning, ini berarti waktu penembakan tinggal tersisa 30 detik.

Selanjutnya untuk waktu penembakan, untuk babak kualifikasi 240 detik dengan menembakan 6 anak panah x 6 seri dan untuk babak eliminasi individu 120 detik dengan menembakan 3 anak panah $\mathrm{x}$ 5 seri. Selanjutnya untuk ukuran target face harus disesuaikan dengan peraturan yang berlaku, seperti untuk Divisi Compound jarak pertandingan 50 meter menggunakan target face ukuran $80 \mathrm{~cm}$ ring 6 , untuk Divisi Recurve jarak pertandingan 70 meter menggunakan target face ukuran $122 \mathrm{~cm}$ full ring. Divisi Standar Bow jarak pertandingan 40 meter menggunakan target face ukuran $80 \mathrm{~cm}$ ring 6 dan Divisi Barebow jarak pertandingan 50 meter menggunakan target face ukuran $122 \mathrm{~cm}$ full ring. Tentunya baik jarak dan juga target face bisa disesuaikan apabila ada kategori kelompok umur yang dipertandingkan.

Pada pukul 14.30 WIB sampai dengan 15.00 WIB dilaksanakan coffee break kedua dialnjut dengan pelaksanaan sholat ashar. Kemudian materi ke empat dimulai pada pukul 15.30 WIB sampai dengan pukul 17.00 WIB. Hal lain yang penting dalam proses perlombaan panahan ialah pada saat 


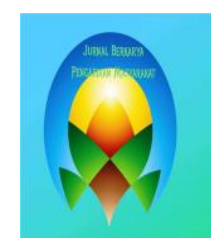

Journal Berkarya

Pengabdian kepada Masyarakat

Vol. 2, No. 1, Mei, 2020,

E-ISSN 2686-6218

pencatatan skor, karena pada saat pencatatan skor dilakukan oleh pemanah sendiri dan tidak disaksikan oleh wasit. Ini akan menjadi ajang kejujuran dari pemanah sendiri.

Akan tetapi ada prosedur yang harus dilakukan oleh para pemanah untuk mencatat skor, seperti yang menulis skor ialah para pemanah sendiri dengan saling memperhatikan satu sama lain (tiap atlet dalam 1 target butt), menuliskan skor dari angka terbesar ke angka terkecil, memastikan skor yang ditulis sesuai dengan anak panah yang tertancap pada target face, tidak boleh mencabut anak panah sebelum proses pencatatan skor selesai dan apabila anak panah dicabut sebelum tercatat pada soring sheet maka akan dianggap nol, dan yang terakhir pastikan menjumlahkan pada tiap seri serta mencatatkan total skor diakhir babak kualifikasi atau pada seri ke enam.

Langkah-langkah proses skoring ini seringkali terjadi kesalahan yang dilakukan oleh para pemanah, apalagi para pemanah pemula yang baru saja mengikuti kejuaraan panahan. Proses penyampaian materi ditutup dengan kegiatan diskusi dan tanya jawab serta pemberian doorprize untuk para peserta dan pelaksanaan postposttest.

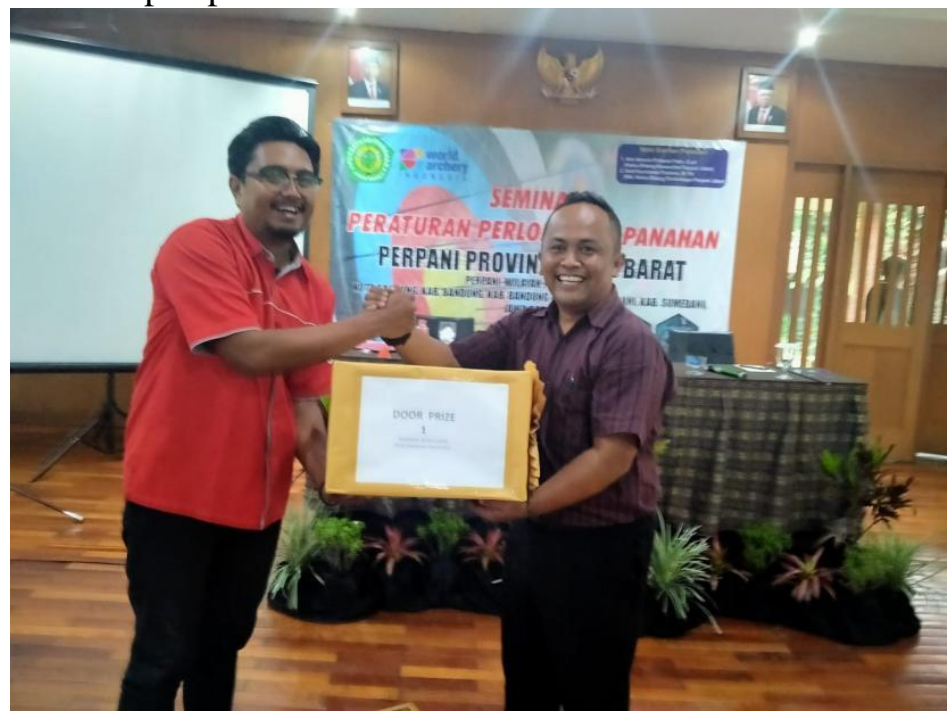

Gambar 1. Pemberian Doorprize (Dok Pribadi)

\section{HASIL DAN PEMBAHASAN}

Permasalahan yang sering terjadi dalam perlombaan panahan ialah masih banyaknya pemanahpemanah pemula beserta pelatih maupun manajer yang belum memahami betul peraturan pelombaan panahan. Hal yang sering kali terjadi ialah pemanah tidak tahu bagaimana proses skoring dilakukan, ataupun masih banyak yang memakai celana jeans dan tidak memakai sepatu. Hal ini disebabkan karena kurang pahamnya pengetahuan dan pemahaman para pemanah dan juga pelatih terhadap peraturan perlombaan panahan.

Padahal secara garis besar, peraturan perlombaan suatu pertandingan akan disebarkan melalui Technical Handbook kejuaraan. Menurut (Duhe, 2014) Kegiatan pengabdian kepada masyarakat melalui sosialisasi peraturan sangat penting bagi masyarakat Sasaran dari kegiatan sosialisasi ini ialah para pecinta olahraga panahan baik itu atlet, pelatih klub, pelatih ekskul panahan ataupun para penghobi yang ada di lingkungan Priangan Tengah meliputi daerah Kota Bandung, Kabupaten Bandung, Kabupaten Bandung Barat, Kota Cimahi dan Kabupaten Sumedang. Susunan Acara Sosialisasi Peraturan Perlombaan Panahan 29 Februari 2020, sebegai berikut:

\begin{tabular}{|c|c|l|}
\hline No & Waktu & \multicolumn{1}{c|}{ Kegiatan } \\
\hline \multirow{4}{*}{1} & $07.30-08.30$ & Registrasi Ulang \\
\cline { 2 - 3 } & $08.30-10.00$ & Materi 1 - Safety \& Target Layout in Archery \\
\cline { 2 - 3 } & $10.00-10.30$ & Coffee Break \\
\cline { 2 - 3 } & $10.30-12.00$ & Materi 2 - Inspection Procedures \\
\cline { 2 - 3 } & $12.00-13.00$ & ISHOMA \\
\cline { 2 - 4 } & $13.00-14.30$ & $\begin{array}{l}\text { Materi 3 - Peraturan Umum Perlombaan Panahan } \\
\text { (signal timer, target face yang digunakan, standar }\end{array}$ \\
\hline
\end{tabular}




\begin{tabular}{|l|l|l|}
\hline & & ukuran lapangan perlombaan, ukuran target butt) \\
\cline { 2 - 3 } & $14.30-15.30$ & Coffee Break \& Sholat \\
\cline { 2 - 3 } & $15.30-17.00$ & Materi 4 - Scoring (Prosedur) \\
\hline
\end{tabular}

Materi sosialiasi peraturan perlombaan ini terbagi menjadi 4 materi dengan dibagi menjadi 2 sesi. Sesi pertama diberikan 2 materi yakni (1) Safety \& Target Layout in Archery dan (2) Inspection Procedures. Selanjtnya sesi kedua diberikan 2 materi yakni (1) Peraturan Umum Perlombaan Panahan (Tata Cara Penembakan, Signal Timer, Target Face) dan (2) Scoring Procedures. Untuk mengetahui apakah terdapat dampak atau tidaknya dari kegiatan ini bagi para peserta maka diberikan pertanyaan seputar peraturan perlombaan panahan dalam bentuk multiple choice sebanyak 20 soal. Adapun hasil dari kegiatan ini dapat dilihat pada diagram 1 berikut ini:

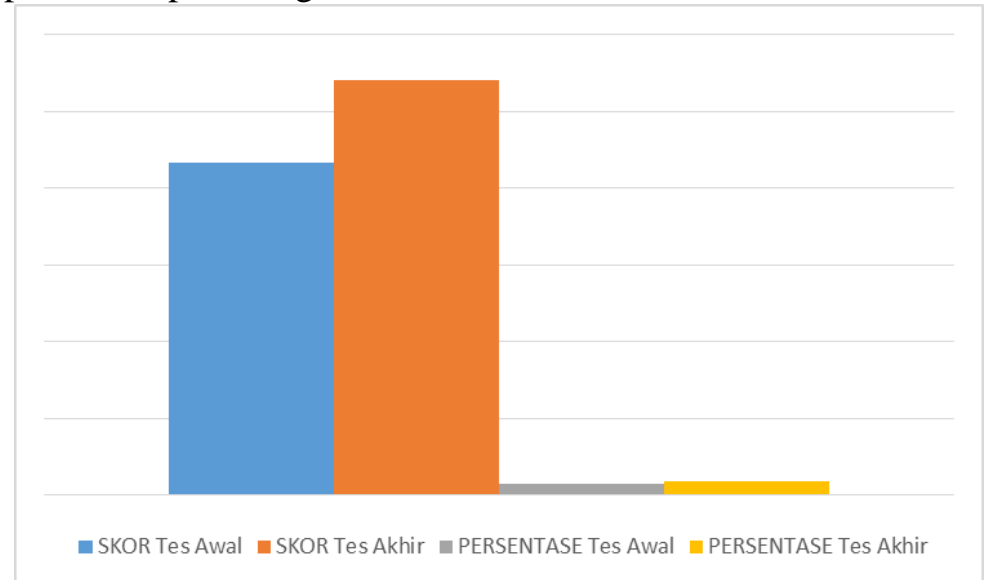

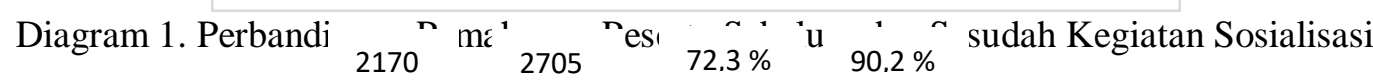

Dari diagram diatas maka dapat diketahui bahwa kegiatan sosialisasi peraturan perlombaan panahan yang telah diberikan kepada para peserta pecinta olahraga panahan di lingkungan Priangan Tengah Jawa Barat dapat meningkatkan pemahaman mengenai peraturan-peraturan perlombaan panahan. Hal ini terlihat ada peningkatan persentase dari sebelum dan sesudah kegiatan ini sebesar $17,8 \%$. Sehingga kedepanya para pemanah pemula, pelatih klub ataupun pelatih ekskul yang megikuti kejuaraan panahan dapat mengikutinya dengan baik dan benar sesuai dengan peraturan perlombaan yang berlaku.

\section{Diskusi}

Suksesnya suatu kejuaraan panahan salah satunya ialah tidak adanya kendala teknis di lapangan, dimana semua pemanah ataupun pelatih memahami betul bagaimana peraturan perlombaan yang berlaku. Hal ini akan menjadi keuntungan bagi pemanah ataupun pelatih karena dipastikan akan mengikuti kejuaraan dengan sebaik-baiknya tanpa adanya kesalahan apapun yang dapat merugikan.

Menurut (Sitepu, 2018) menjelaskan tentang beberapa faktor yang mempengaruhi permainan yaitu adalah peraturan pertandingan dan perlombaan suatu cabang Peraturan perlombaan panahan sejatinya sudah diatur oleh World Archery sebagai induk organisasi olahraga panahan di dunia dan bisa di download melalui situa worldarchery.org, akan tetapi kebanyakan pemanah pemula mendapatkan peraturan perlombaan melalui klub-klubnya yang ditransfer oleh pelatih. Maka dapat dikatakan apabila pelatihnya kurang memahami peraturan perlombaan akan berdampak pada atletnya ketika mengikuti kejuaraan panahan. Selain itu, pedoman peraturan perlombaan sudah disebarkan oleh panitia perlombaan melalui Technical Handbook kejuaraan.

Melalui kegiatan sosialisasi peraturan perlombaan panahan ini diharapkan para peserta yang terdiri dari atlet maupun pelatih dapat menerapkannya pada saat mengikuti kejuaraan dengan benar sehingga tidak terjadi kendala teknis dilapangan.

\section{KESIMPULAN}

Berdasarkan hasil kegiatan yang dijelaskan dapat diperoleh kesimpulan adanya peningkatan pemahaman atlet maupun pelatih panahan baik level klub ataupun ekskul terhadap peraturan 
perlombaan panahan sebesar $17,8 \%$. Jalanya kegiatan sosialisasi perlombaan panahan ini melalui metode sosilisasi yang terbagi ke dalam 3 tahap (Orientasi, Implementasi dan Evaluasi). Melalui kegiatan ini berhasil memberikan tambahan pengetahuan mengenai peraturan perlombaan bagi para peserta yang diharapkan mampu untuk melaksanakannya dengan benar.

\section{PENGAKUAN}

Keberhasilan kegiatan ini tentunya tidak lepas dari berbagai kekurangan dan keterbatasan kami oleh karena itu kami haturkan terima kasih Rektor Universitas Suryakancana dan Dekan Fakultas Keguruan Dan Ilmu Pendidikan Pengda Perpani Jawa Barat cc Bid Perlombaan, Pengcab Perpani Kota Bandung, Pengcab Perpani Kabupaten Bandung, Pengcab Perpani Kabupaten Bandung Barat, Pengcab Kota Cimahi, Pengcab Kabupaten Sumedang beserta Klub-klub yang ada di wilayah Priangan Tengah Jawa Barat.

\section{DAFTAR PUSTAKA}

duhe, E. D. P. (2014). Sosialisasi Peraturan Permainan Tinju Pada Guru-Guru Penjas Se-Kecamatan Anggrek Kabupaten Gorontalo Utara.

Ilham, W. J. D., \& Oktadinata, A. (2018). Sosialisasi Dan Coaching Clinic Teknik Dasar Futsal Pada Smp N 11 Kota Jambi. Jurnal Cerdas Sifa, 1(2), 9-15.

Ms. Taufik. (2019). Hubungan Tingkat Konsentrasi Dengan Keterampilan Bermain Futsal Unit Kegiatan Mahasiswa Futsal Universitas Suryakancana Dalam Olahraga. Gladi Jurnal Unj, 10(02), 68-78. Https://Doi.Org/Doi : Https://Doi.Org/10.21009/Gjik.102.01

Prasetyo, Y. (2011). Teknik-Teknik Dasar Bagi Atlet Pemula Panahan. Journal Uy.

Rahadian, A. (2018). Mengembangkankemampuan Lari Jarak Pendek ( 100 M ) Mahasiswa Pjkrunsur ( Kinovea Software ). Maenpo, 8(1), 1.

Sitepu, I. D. (2018). Manfaat Permainan Bola Basket Untuk Anak Usia Dini. Jurnal Prestasi, 2(3), 27. Https://Doi.Org/10.24114/Jp.V2i3.10129

World Archery. (2019). Peraturan Pertandingan Archery.

Zarwan, Sefri Hardiansyah, A. Z. (2019). Sosialisasi Shuttle Time Bulutangkis Bagi Guru Pendidikanjasmani Olahraga Dan Kesehatan Tingkat Sekolah Dasar Di Kecamatan Padang Utara. Journal Humanities, 1(1), 67-72. 